DOI: https://doi.org/10.47405/mjssh.v6i4.762

\begin{tabular}{|c|c|}
\hline 4.581 & Malaysian Journal of Social Sciences and Humanities (MJSSH) \\
\hline $\begin{array}{l}\text { Malaysian Journal of } \\
\text { Social cciences and }\end{array}$ & Volume 6, Issue 4, April 2021 \\
\hline (MJ-SSH) & e-ISSN : 2504-8562 \\
\hline & $\begin{array}{l}\text { Journal home page: } \\
\text { www.msocialsciences.com }\end{array}$ \\
\hline
\end{tabular}

\title{
Hubungan Strategi Metakognitif Membaca Teks dengan Jantina dan Pencapaian Pelajar dalam Pembelajaran Bahasa Arab
}

\author{
Siti Fatimah binti Datu Ali Nafiah ${ }^{1}$ \\ 1Fakulti Psikologi dan Pendidikan, Universiti Malaysia Sabah (UMS) \\ Correspondence: Siti Fatimah binti Datu Ali Nafiah (ftdan550@gmail.com)
}

\begin{abstract}
Abstrak
Pemahaman dalam proses pembacaan memerlukan strategi bagi menetapkan tujuan dan meningkatkan fokus pembacaan khususnya dalam perkembangan pembelajaran kendiri. Kajian ini bertujuan untuk meninjau tahap strategi metakognitif membaca teks dan hubungannya dengan jantina dan pencapaian akademik dalam kalangan pelajar bahasa Arab, UKM. Kajian kuantitatif berbentuk tinjauan ini menggunakan soal selidik sebagai instrumen. Kajian ini melibatkan seramai 30 orang responden yang dipilih melalui persampelan rawak mudah. Penumpuan diberikan kepada responden yang telah mengikuti kursus bahasa Arab di Fakulti Pengajian Islam, UKM. Data yang diperolehi dianalisis secara deskriptif dan inferensi. Dapatan kajian menunjukkan penggunaan strategi metakognitif membaca teks berada pada tahap yang sederhana, secara terperinci strategi global berada pada tahap sederhana diikuti strategi sokongan dan strategi penyelesaian masalah juga digunakan secara sederhana dalam pembelajaran bahasa Arab. Namun begitu tidak terdapat perbezaan dan hubungan yang signifikan skor min strategi metakognitif membaca teks antara jantina dan pencapaian pelajar. Pengajaran dan pembelajaran yang menerapkan kesedaran strategi metakognitif dapat dipupuk dalam pengajaran guru dalam aktiviti pengajaran dan pembelajaran bahasa Arab. Tenaga pendidik bahasa Arab dapat memanfaatkan hasil kajian untuk merancang pengajaran dan pembelajaran dengan memupuk kesedaran strategi metakognitif dalam proses pembelajaran teks Arab.
\end{abstract}

Kata kunci: strategi pembelajaran, strategi membaca, strategi metakognitif, pembelajaran bahasa Arab

\section{The Relations Between Metacognitive Strategy of Reading Text With Gender and Student's Achievement in Learning Arabic Language}

\begin{abstract}
Understanding in the reading process requires a strategy for setting goals and enhancing the focus of reading especially in the development of self-study. The purpose of this study is to examine the level of metacognitive strategy of reading the text and its relationship with gender and academic achievement among Arabic, UKM students. The quantitative study of this survey uses a questionnaire as an instrument. This study involved 30 respondents selected through simple random sampling. Concentration is given to respondents who have attended Arabic courses at the Faculty of Islamic Studies, UKM. The data obtained were analyzed descriptively and inferred. The findings show that the use of metacognitive text reading strategies is at a moderate level, in detail the global strategy is at a moderate level followed by a support strategy and problem solving strategy is also used moderately in Arabic language learning. However there was no significant difference and significant relationship between the mean score of the metacognitive strategy reading the text between the gender and student
\end{abstract}


achievement. Teaching and learning that incorporate the awareness of metacognitive strategies can be nurtured in teacher's teaching in Arabic language teaching and learning activities. Arabic language educators can utilize the results of the study to plan teaching and learning by fostering the awareness of metacognitive strategies in the process of learning Arabic texts.

Keywords: learning strategy, reading strategy, metacognitive strategy, learning arabic language

\section{Pengenalan}

Pembelajaran bahasa bagi tujuan akademik memerlukan strategi bagi meningkatkan pemahaman dan fokus dalam proses pembelajaran. Salah satu strategi pembelajaran yang dapat mengoptimakan pemahaman dan fokus dalam pembelajaran adalah strategi metakognitif dan ia penting dalam pembentukan dan perkembangan pembelajaran kendiri. Sehubungan itu, strategi dalam proses pembelajaran diperlukan agar menambah kesedaran dan keupayaan pelajar menggunakan strategi pembelajaran khususnya dalam pembelajaran bahasa. Pelbagai kajian lepas (Shikano, 2013; Tavakoli, 2014; Fitrisia et al., 2015;) menunjukkan penggunaan strategi metakognitif membaca penting dalam pembelajaran pemahaman bahasa. Hal ini turut ditekankan oleh Chamot (2001), (dalam Breen 2001) bahawa penerapan strategi dalam proses pembelajaran bahasa semakin mendapat perhatian dalam bidang kajian pengajaran dan pembelajaran (PdP) bahasa. Kajian penerapan strategi metakognitif telah dilaksanakan oleh Khonamri \& Kojidi (2011) dalam pengajaran dan pembelajaran (PdP) bahasa dan menunjukkan terdapat hubungan yang signifikan antara penggunaan strategi metakognitif dalam pembelajaran bahasa kedua dan bahasa asing dengan kebolehan pemahaman dalam kemahiran membaca.

Namun begitu wujud isu apabila pelajar bahasa sering menghadapi masalah dalam penggunaan pengetahuan bahasa seperti fonologi, sintaksis, morfologi dan semantik (Azman \& Goh, 2010) serta kurang kesedaran strategi dan pemahaman dalam pembelajaran kemahiran bahasa khususnya dalam pengajaran dan pembelajaran kemahiran membaca (Alsheikh \& Mokhtari, 2011; Shikano, 2013; Keshavars \& Ghamoushi, 2014; Tavakoli, 2014; Fitrisia, 2015). Hal ini dapat dikaitkan dengan dilema pelajar dalam menetapkan perhatian dan masa untuk pembelajaran (McCabe, 2011). Sehubungan itu, dapatan kajian lepas jelas menunjukkan kesedaran strategi metakognitif yang dilaksanakan oleh para pengkaji lepas memberi input terkini bagi kajian lanjutan. Selain itu, dapatan kajian tersebut menunjukkan signifikan dan keperluan strategi metakognitif khususnya strategi membaca teks dalam proses pembelajaran. Senario ini mendorong pengkaji untuk meninjau tahap strategi metakognitif membaca teks dan hubungannya dengan jantina dan pencapaian akademik dalam kalangan pelajar bahasa Arab, UKM.

Secara terperinci, objektif kajian adalah untuk mengenal pasti perbezaan strategi metakognitif membaca teks mengikut jantina dan pencapaian pelajar ketika mempelajari bahasa Arab. Disamping itu, objektif lain adalah mengenal pasti hubungan strategi metakognitif membaca teks mengikut jantina dan pencapaian pelajar ketika mempelajari bahasa Arab. Justeru, konteks utama dalam kajian ini adalah untuk melihat sejauh mana strategi metakognitif membaca teks digunakan oleh pelajar dalam pembelajaran bahasa Arab. Strategi metakognitif dalam membaca teks merujuk kepada strategi yang digunakan dalam proses pembacaan untuk memahami teks. Menurut Takavoli (2014), penggunaan strategi metakognitif dalam proses pembacaan merupakan strategi yang memberi manfaat terhadap keupayaan kognitif, sosial dan linguistik individu. Antara strategi metakognitif membaca teks yang digunakan dalam proses pembacaan adalah strategi membaca secara global, strategi penyelesaian masalah dan strategi membaca sokongan (Alhaqbani \& Riazi, 2012).

Umumnya, Fitrisia et al. (2015) menyatakan bahawa strategi membaca global merupakan suatu set strategi membaca berorientasi ke arah analisis teks secara global. Secara terperinci, strategi membaca global merupakan strategi generalisasi yang bertujuan untuk menetapkan peringkat tindakan dalam pembacaan (Alsheikh \& Mokhtari, 2011; Tavakoli, 2014). Antara strategi membaca global ialah menetapkan tujuan membaca, melihat semula dan meramal isi kandungan teks bacaan (Shikano, 2013). 
Manakala strategi membaca penyelesaian masalah merujuk kepada strategi kebiasaan yang fokus terhadap penyelesaian masalah atau dikenali juga sebagai strategi penambahbaikan apabila terdapat masalah kefahaman penyampaian maklumat dalam teks (Shikano, 2013; Tavakoli, 2014). Fitrisia et.al (2015) menyatakan bahawa strategi membaca penyelesaian masalah menekankan strategi untuk menyelesaikan masalah apabila menghadapi masalah dalam pembacaan. Antara strategi membaca penyelesaian masalah ialah memeriksa pemahaman terhadap maklumat yang membawa konflik dalam pembacaan dan membaca semula bagi menambah kefahaman (Shikano, 2013).

Strategi membaca sokongan pula menggunakan mekanisme atau alat bertujuan untuk mengekalkan tindak balas terhadap bacaan dan menggunakan bahan-bahan rujukan luar (Shikano, 2013; Tavakoli, 2014; Fitrisia, 2015). Albazi dan Shukri (2016) pula menyatakan bahawa strategi membaca sokongan menggunakan strategi berbentuk fungsi yang melibatkan penggunaan bahan rujukan luar seperti kamus, pengambilan nota dan rumusan untuk membantu mencapai matlamat tertentu dalam tugasan bacaan. Antara strategi membaca sokongan ialah menggariskan atau membulatkan maklumat, menjelaskan semula bagi tujuan menambah kefahaman dan mengimbas semula teks (Shikano, 2013; Tavakoli, 2014).

Secara keseluruhan, kajian membincangkan tentang kepentingan, strategi metakognitif dalam proses membaca dan proses pemahaman para pelajar bahasa berdasarkan sorotan literatur. Dapatan kajian lepas (Shikano, 2013; Tavakoli, 2014; Fitrisia, 2015) menunjukkan bahawa strategi metakognitif yang digunakan dalam pemahaman bacaan iaitu strategi membaca global, strategi membaca penyelesaian masalah, dan strategi membaca sokongan mempunyai hubungan dengan kesedaran dalam strategi pembelajaran. Seterusnya, penjelasan metod kajian dan prosedur kajian diutarakan mengikut reka bentuk kajian. Manakala, dapatan kajian dianalisis dan dibincangkan mengikut perincian objektif kajian. Akhir sekali, implikasi dan saranan lanjutan dibahaskan dengan mengaitkan dapatan kajian dengan dapatan kajian lepas.

\section{Sorotan Literatur}

Secara umumnya, pelbagai kajian lepas telah dilaksanakan bagi mengenal pasti kesedaran strategi metakognitif dalam kalangan pelajar. Nur Aisyah et al. (2013) membahaskan pendedahan dan penekanan terhadap unsur metakognitif dalam unsur pengajaran dan pembelajaran kerana ia merupakan satu kemahiran yang boleh dipelajari oleh murid. Sehubungan itu, kebanyakan kajian yang dilaksanakan tentang strategi metakognitif dalam pembelajaran dan pengajaran membincangkan hubungan metakognitif dengan kesedaran dalam strategi membaca teks.

Terdapat beberapa sarjana yang membincangkan konsep metakognitif mengikut konteks kesedaran dalam teori metakognitif. Antaranya, Flavell dan Wellman (1977), Flavell (1979), O’Neil dan Abedi (1996) serta O’Neil dan Schacter (1997) yang menyatakan bahawa metakognitif merujuk kepada kesedaran seseorang tentang pengetahuan dan pengawalan seseorang terhadap proses kognitif yang diperlukan dalam pembelajaran. Manakala Goh (2010) pula menambah bahawa metakognitif dapat membimbing individu untuk memilih dan menilai serta mengulang kaji atau tidak dalam sesuatu tugasan, tujuan, dan strategi atau dalam erti kata lain untuk menetapkan regulasi kendiri terhadap pembelajaran dan pemikiran. Oleh itu, proses pembelajaran memerlukan pengetahuan dan pengalaman kendiri dalam kesedaran metakognitif.

Namun begitu, Flavel (1976) menyatakan secara spesifik bahawa metakognitif merupakan pengetahuan individu yang melibatkan proses dan hasil dari proses kognitif atau apa sahaja yang berkaitan dengan proses kognitif dan ia terbahagi kepada tiga jenis pengetahuan iaitu pengetahuan kendiri, pengetahuan tugasan dan pengetahuan strategi. Pengetahuan kendiri melibatkan kepercayaan pelajar terhadap kemampuan diri dan kemampuan individu lain sebagai pemproses kognitif. Wenden (1998) dalam Fitrisia (2015) menyatakan bahawa pengetahuan tugasan dirujuk sebagai pengetahuan pelajar tentang tujuan, keperluan dan sifat semula jadi tugasan pembelajaran. Manakala, pengetahuan strategi pula melibatkan strategi berkesan dalam mencapai tujuan mengikut aktiviti kognitif. 
Penggunaan strategi metakognitif melibatkan keupayaan individu dan telah dinyatakan oleh beberapa pengkaji lepas sebagai kemampuan dalam proses metakognitif. Menurut Flavell (1987) (dalam Mazli Sham \& Saemah 2014), pengetahuan dan pengawalan seseorang terhadap proses pembelajaran ke atas aktiviti pemikiran dan pembelajaran menunjukkan proses metakognitif. Menurut Paris dan Winograd (1990) kemampuan dalam penggunaan strategi metakognitif dapat meningkatkan pembelajaran secara akademik dan daya motivasi.

Strategi metakognitif membaca teks merujuk kepada salah satu strategi membaca iaitu strategi metakognitif. Strategi metakognitif membaca seperti dalam kajian Alsheikh dan Mokhtari (2011) dibahagikan kepada tiga konstruk strategi membaca iaitu strategi membaca secara global, strategi membaca secara penyelesaian masalah dan strategi membaca untuk sokongan. Strategi metakognitif membaca teks seperti dalam kajian Alhaqbani dan Riazi (2012) merujuk kepada skor min kesedaran pelajar terhadap strategi membaca ketika membaca teks Arab bagi tujuan pembelajaran. Sehubungan itu, pelbagai kajian mengenai strategi metakognitif membaca telah dilaksanakan oleh para pengkaji lepas. Dapatan kajian tersebut menunjukkan signifikan dan keperluan strategi metakognitif khususnya membaca teks dalam proses pembelajaran. Berdasarkan dapatan kajian lepas, skor min yang dicatatkan berbeza bagi setiap strategi membaca.

Hal ini direkodkan dalam kajian yang dilaksanakan oleh Alhaqbani dan Riazi (2012) yang menunjukkan bahawa kesedaran strategi metakognitif membaca teks pembelajaran pelajar dalam kursus bahasa Arab sebagai bahasa kedua di King Saud University di Arab Saudi menunjukkan skor min yang berbeza bagi konstruk strategi membaca global $(\min =3.43,3.64)$, strategi penyelesaian masalah $(\min =3.39,4.14)$ dan strategi membaca sokongan $(\min =3.35,3.66)$ berdasarkan interpretasi skor min pelajar mengikut tempoh semester pengajian di universiti iaitu 1 hingga 4 semester dan 5 hingga 8 semester. Hasil kajian menunjukkan strategi penyelesaian masalah merupakan strategi yang sering digunakan pelajar dalam proses pemahaman bacaan teks.

Manakala dapatan kajian yang dilaksanakan oleh Shikano (2013) terhadap penggunaan strategi membaca teks bahasa Inggeris di universiti Jepun dalam pembelajaran bahasa Inggeris menunjukkan bahawa skor min strategi membaca global lebih rendah $(\min =3.42)$ berbanding strategi penyelesaian masalah $(\min =3.80)$. Manakala strategi membaca sokongan $(\min =3.47)$ berdasarkan interpretasi skor min adalah kedua rendah setelah strategi penyelesaian masalah yang mencatatkan skor min tinggi.

Seterusnya, kajian kes oleh Tavakoli (2014) tentang keberkesanan kesedaran strategi metakognitif terhadap pemahaman bacaan teks dalam kalangan pelajar bahasa Inggeris sebagai bahasa kedua di Iran menunjukkan bahawa skor min strategi membaca sokongan lebih tinggi $(\min =3.26)$ berbanding strategi membaca global $(\min =2.91)$ dan strategi membaca penyelesaian masalah $(\min =2.37)$. Dapatan kajian turut mencatatkan bahawa ketiga-ketiga kategori strategi membaca teks mempunyai hubungan dengan pemahaman dalam pembacaan para pelajar. Disamping itu, kesedaran metakognitif terhadap strategi membaca mempunyai hubungan dengan tahap penguasaan bahasa iaitu pengusaan bahasa tahap tinggi $(\min =3.54)$, penguasaan bahasa sederhana $(\min =2.62)$ dan rendah $(\min =2.15)$. Hal ini menunjukkan penguasaan bahasa mampu mempengaruhi strategi membaca yang digunakan oleh para pelajar dalam proses pemahaman teks.

Hasil kajian yang dilaksanakan oleh Al-Dawaideh (2013) menunjukkan terdapat perbezaan signifikan strategi global, strategi penyelesaian masalah dan strategi sokongan berdasarkan jantina. Hasil dapatan menunjukkan pelajar perempuan mempunyai nilai min yang lebih tinggi dan strategi yang kebiasaanya digunakan adalah strategi penyelesaian masalah.

Disamping itu, pemahaman teks berkait rapat dengan pencapaian akademik pelajar seperti yang dilaporkan dalam kajian Fitrisia et al. (2015) berkenaan kesedaran metakognitif terhadap strategi membaca menunjukkan pemahaman dalam pembacaan teks mempengaruhi pencapaian pelajar dalam pembelajaran bahasa Inggeris. Dapatan kajian menunjukkan bahawa terdapat hubungan yang signifikan antara kesedaran metakognitif terhadap strategi membaca dengan penguasaan pemahaman bacaan ( $\mathrm{r}=.144$ dan $\mathrm{sig}=.017)$. Selain itu, terdapat perbezaan strategi metakognitif antara pembaca lemah, sederhana dan pelajar yang mempunyai penguasaan penuh dalam pembacaan. Hasil kajian juga 
menunjukkan terdapat perbezaan kesedaran strategi metakognitif membaca iaitu strategi membaca global $(\min =3.24)$, strategi membaca penyelesaian masalah $(\min =3.66)$ dan strategi membaca sokongan $(\min =3.13)$.

\section{Metod Kajian}

Kajian ini bertujuan untuk mengenal pasti tahap kesedaran metakognitif para pelajar di institusi pengajian tinggi ketika mempelajari bahasa Arab. Kajian kuantitatif berbentuk tinjauan digunakan dengan mengedarkan borang soal selidik. Analisis deskriptif dan inferensi digunakan untuk mencari peratusan dan min dan menjawab hipotesis kajian bagi data yang dikumpulkan dalam kajian. Prosedur persampelan rawak mudah digunakan dan dapat membantu pengkaji mendapatkan sampel kajian daripada ketiga-tiga kumpulan sampel pelajar.

Kajian ini melibatkan pelajar prasiswazah yang telah mengikuti kursus bahasa Arab sebagai populasi target daripada keseluruhan populasi pelajar di Fakulti Pengajian Islam (FPI), Universiti Kebangsaan Malaysia (UKM). Hal ini kerana, rasional pemilihan sampel berdasarkan keutamaan fokus kajian iaitu strategi metakognitif membaca teks dalam kalangan pelajar bahasa Arab, UKM. Responden kajian ini merangkumi pelajar yang mengambil kursus kemahiran bahasa Arab pada setiap semester iaitu seramai 30 orang yang dipilih menggunakan persampelan secara rawak berstrata.

Soal selidik Metacognitive Awareness of Reading Strategies yang dihasilkan oleh Mokhtari dan Richard (2002) diadaptasi sebagai instrumen kajian bagi mengenal pasti tiga faktor kajian iaitu strategi membaca global, strategi penyelesaian masalah dan strategi membaca sokongan. Instrumen ini telah diubahsuai dan mengandungi tiga subskala iaitu strategi membaca global, strategi membaca penyelesaian masalah dan strategi membaca sokongan.

Data yang diperoleh dianalisis menggunakan Statistic Packages for Social Science (SPSS) versi 20. Penganalisisan dibuat menerusi analisis deskriptif dan inferensi dengan menggunakan ujian MANOVA bagi menguji perbezaan dan korelasi Spearman-Rho untuk menguji hubungan antara pemboleh ubah. Skala likert 5 markah, iaitu 1- langsung tidak pernah, 2- hampir tidak pernah, 3-kadang-kadang, 4hampir selalu, 5- sangat selalu digunakan bagi mengenal pasti tahap strategi metakognitif membaca teks pelajar. Nilai min dirujuk daripada Nik Nur Fadhillah (2015), iaitu min 1.00-2.33 tahap rendah, min 2.34-3.66 tahap sederhana dan min 3.67-5.00 tahap tinggi.

\section{Hasil Kajian}

Hasil kajian mendapati seramai 30 orang pelajar telah melibatkan diri dalam kajian ini. Kesemua pelajar yang terlibat dalam kajian ini adalah pelajar bahasa Arab dari Fakulti Pengajian Islam, UKM.

\section{Maklumat Demografi Responden}

Jadual 1 menunjukkan taburan dan peratusan profil responden merangkumi jantina, umur, tahun pengajian, pencapaian akademik (PNGK) dan pencapaian bahasa Arab (Gred). Berdasarkan jadual di bawah, seramai 21 orang $(70 \%)$ adalah pelajar lelaki dan seramai sembilan orang (30\%) merupakan pelajar perempuan. Manakala demografi berdasarkan umur pula menunjukkan seramai 24 orang $(80 \%)$ adalah pelajar yang berumur 21-23 tahun, lima orang berumur 24-26 tahun dan seorang sahaja berumur 19-20 tahun.

Manakala demografi pencapaian akademik pelajar menunjukkan kesemua pelajar memperoleh keputusan PNGK 3.00-4.00. Selain itu, kebanyakan pelajar memperoleh gred A- dalam mata pelajaran bahasa Arab iaitu 18 orang $(60 \%)$ diikuti gred B+ iaitu lima orang $(16.7 \%)$, kemudian gred A seramai empat orang (13.3\%), dua orang (6.7\%) mendapat gred B- dan seorang (3.3\%) memperoleh gred B. 
DOI: https://doi.org/10.47405/mjssh.v6i4.762

Jadual 1: Maklumat Demografi Responden

\begin{tabular}{|c|c|c|c|}
\hline $\begin{array}{l}\text { Demografi } \\
\text { Responden }\end{array}$ & Maklumat & Frekuensi $(f)$ & Peratus (\%) \\
\hline \multirow[t]{6}{*}{ Jantina } & Lelaki & 21 & $70^{\circ}$ \\
\hline & Perempuan & 9 & 30 \\
\hline & A & 4 & 13.3 \\
\hline & A- & 18 & 60 \\
\hline & $\mathrm{B}+$ & 5 & 16.7 \\
\hline & $\mathrm{B}$ & 1 & 3.3 \\
\hline \multirow{6}{*}{$\begin{array}{l}\text { Pencapaian } \\
\text { Arab (Gred) }\end{array}$} & B- & 2 & 6.7 \\
\hline & $\mathrm{C}+$ & 0 & 0 \\
\hline & $\mathrm{C}$ & 0 & 0 \\
\hline & $\mathrm{C}-$ & 0 & 0 \\
\hline & $\mathrm{D}$ & 0 & 0 \\
\hline & $\mathrm{E}$ & 0 & 0 \\
\hline
\end{tabular}

\section{Tahap Strategi Metakognitif Membaca Teks}

Apakah tahap penggunaan strategi metakognitif membaca teks dalam kalangan pelajar bahasa Arab, UKM? Bagi menjawab persoalan kajian tersebut, analisis deskriptif digunakan untuk memerihalkan dapatan dalam bentuk skor min dan sisihan piawai. Dapatan kajian mengenai strategi metakognitif membaca teks yang melibatkan tiga kosntruk ditunjukkan menerusi jadual 2.

Jadual 2: Min, Sisihan Piawai dan interpretasi Strategi Metakognitif Membaca Teks

\begin{tabular}{lccc}
\hline \multicolumn{1}{c}{ Strategi Metakognitif Membaca } & N & Min & Sisihan Piawai \\
\hline Strategi Membaca Global & 30 & 3.60 & .454 \\
Strategi Membaca Penyelesaian & 30 & 3.57 & .419 \\
Masalah & & & .453 \\
Strategi Membaca Sokongan & 30 & 3.58 & .403 \\
Jumlah Strategi Metakognitif & 30 & 3.58 & \\
Membaca Teks & & & \\
\hline
\end{tabular}

Berdasarkan jadual 2, skor min tertinggi adalah strategi membaca global $(\mathrm{M}=3.60, \mathrm{SP}=.454)$, kemudian strategi membaca sokongan $(\mathrm{M}=3.58, \mathrm{SP}=.453)$ dan diikuti strategi membaca sokongan $(\mathrm{M}=3.57$, $\mathrm{SP}=$.419) diikuti dan . Namun begitu, secara keseluruhan penggunaan strategi metakognitif membaca teks berada pada tahap sederhana $(\mathrm{M}=3.58, \mathrm{SP}=.403)$.

\section{Perbezaan Strategi Metakognitif Membaca Teks Mengikut Jantina}

Adakah terdapat perbezaan strategi metakognitif membaca teks (strategi membaca global, strategi membaca penyelesaian masalah dan strategi membaca sokongan) mengikut jantina pelajar ketika mempelajari bahasa Arab? Bagi menjawab persoalan kajian tersebut, analisis MANOVA dilaksanakan untuk mengenal pasti perbezaan strategi metakognitif membaca teks (strategi membaca global, strategi membaca penyelesaian masalah dan strategi membaca sokongan). Hasil analisis ujian MANOVA ditunjukkan dalam jadual 5. Sebelum analisis MANOVA dilaksanakan, ujian matrik kehomogenan varian kovarian ditentukan untuk menetapkan kesesuaian ujian dengan menggunakan ujian Box's $M$ dan ujian Levene seperti yang ditunjukkan dalam jadual 3 dan 4. 
DOI: https://doi.org/10.47405/mjssh.v6i4.762

Jadual 3: Ujian Box's M

\begin{tabular}{ccccc}
\hline Box's M & Nilai F & dK1 & dK2 & $\begin{array}{c}\text { Tahap } \\
\text { Signifikan } \\
(\mathbf{p})\end{array}$ \\
\hline 20.165 & 2.840 & 6 & 1505.506 & .009 \\
\hline
\end{tabular}

Hasil ujian Box's M yang telah dijalankan ke atas jantina seperti yang ditunjukkan dalam jadual 3, didapati terdapat perbezaan varian dan kovarian yang signifikan $[\mathrm{F}=2.840, \mathrm{p}=.009 \quad(\mathrm{p}<0.05)]$ antara pemboleh ubah bersandar dan pemboleh ubah bebas. Hal ini menunjukkan varian bagi ketiga-tiga pembolehubah bersandar merentasi pembolehubah bebas tidak homogen dalam sampel kajian.

Jadual 4: Ujian Levene berdasarkan jantina

\begin{tabular}{lcccc}
\hline $\begin{array}{l}\text { Pemboleh Ubah } \\
\text { Bersandar }\end{array}$ & Nilai F & dK1 & dK2 & $\begin{array}{c}\text { Tahap } \\
\text { Signifikan } \\
(\mathbf{p})\end{array}$ \\
\hline Global & .395 & 1 & & .535 \\
Penyelesaian & .034 & 1 & 28 & .855 \\
Masalah & & & 28 & .535 \\
Sokongan & .395 & 1 & 28 & \\
\hline
\end{tabular}

Kemudian ujian Levene dilaksanakan untuk melihat kesamaan varian bagi pemboleh ubah bersandar merentasi kategori pemboleh ubah bebas yang dikaji. Dapatan ujian Levene seperti jadual 4 menunjukkan bahawa varian dan kovarian bagi semua pembolehubah adalah sama. Nilai yang diperolehi pada pemboleh ubah bersandar iaitu strategi membaca global daripada analisis ujian Levene yang dijalankan adalah tidak signifikan $[\mathrm{F}(1,28)=.395, \mathrm{p}=.535(\mathrm{p}>0.05)]$. Nilai yang tidak signifikan juga ditunjukkan melalui ujian Levene pada pemboleh ubah bersandar strategi membaca penyelesaian masalah $[\mathrm{F}(1,28)=.034, \mathrm{p}=.855(\mathrm{p}>0.05)]$. Pemboleh ubah bersandar strategi membaca sokongan turut sama menunjukkan nilai yang tidak signifikan $[\mathrm{F}(1,28)=.395, \mathrm{p}=.535(\mathrm{p}>0.05)]$. Hal ini menunjukkan tidak terdapat perbezaan varian pada ketiga-tiga pemboleh ubah tersebut.

Jadual 5: Analisis MANOVA perbezaan Strategi Metakognitif Membaca Teks (Global, Penyelesaian Masalah \& Sokongan) berdasarkan jantina

\begin{tabular}{|c|c|c|c|c|c|c|c|}
\hline Kesan & $\mathbf{N}$ & & $\begin{array}{l}\text { Nilai } \\
\text { Pillai } \\
\text { Trace }\end{array}$ & $\begin{array}{c}\text { Nilai } \\
\text { F }\end{array}$ & $\begin{array}{l}\text { dK antara } \\
\text { kumpulan }\end{array}$ & $\begin{array}{l}\text { dK dalam } \\
\text { kumpulan }\end{array}$ & $\begin{array}{c}\text { Tahap } \\
\text { Signifikan } \\
\text { (p) }\end{array}$ \\
\hline Jantina & $\begin{array}{l}\text { Lelaki } \\
\text { Perempuan }\end{array}$ & $\begin{array}{l}21 \\
9\end{array}$ & .024 & .215 & 3.000 & 26.00 & .885 \\
\hline
\end{tabular}

Jadual 5 menunjukkan analisis MANOVA yang dilaksanakan untuk menentukan perbezaan strategi metakognitif membaca teks berdasarkan jantina. Dapatan ujian MANOVA jelas menunjukkan bahawa tidak terdapat perbezaan antara kumpulan lelaki dan perempuan dalam strategi metakognitif membaca teks (strategi global, strategi penyelesaian masalah, strategi sokongan). Hal ini ditunjukkan oleh nilai Pillai's Trace $=.024, \mathrm{~F}=.215$ dan $\mathrm{p}=.885<0.05$. Oleh itu, hipotesis nul yang menyatakan tidak terdapat perbezaan skor min strategi metakognitif membaca teks mengikut jantina gagal untuk ditolak dan menunjukkan bahawa kesemua pelajar menggunakan strategi metakognitif membaca teks ketika mempelajari bahasa Arab.

\section{Perbezaan Strategi Metakogntif Membaca Teks Mengikut Pencapaian Pelajar}

Adakah terdapat perbezaan strategi metakognitif membaca teks (strategi membaca global, strategi membaca penyelesaian masalah dan strategi membaca sokongan) mengikut pencapaian pelajar ketika mempelajari bahasa Arab? Bagi menjawab persoalan kajian tersebut, analisis MANOVA dilaksanakan untuk mengenal pasti perbezaan strategi metakognitif membaca teks (strategi membaca global, strategi membaca penyelesaian masalah dan strategi membaca sokongan). Hasil analisis ujian MANOVA 
DOI: https://doi.org/10.47405/mjssh.v6i4.762

ditunjukkan dalam jadual 8. Sebelum analisis MANOVA dilaksanakan, ujian matrik kehomogenan varian kovarian ditentukan untuk menetapkan kesesuaian ujian dengan menggunakan ujian Box's $M$ dan ujian Levene seperti yang ditunjukkan dalam jadual 6 dan 7.

Jadual 6: Ujian Box’s M

\begin{tabular}{cccc|c}
\hline Box's M & Nilai F & dK1 & dK2 & $\begin{array}{c}\text { Tahap } \\
\text { Signifikan } \\
\text { (p) }\end{array}$ \\
\hline 3.868 & .382 & 6 & 161.978 & .890 \\
\hline
\end{tabular}

Hasil ujian Box's M yang telah dijalankan ke atas pencapaian pelajar seperti yang ditunjukkan dalam jadual 6, didapati tidak terdapat perbezaan varian kovarian $[\mathrm{F}=.382, \mathrm{p}=.890(\mathrm{p}>.05)$ antara pemboleh ubah bersandar dan pemboleh ubah bebas. Hal ini menunjukkan bahawa data menepati syarat kesamaan kovarian, iaitu varian bagi ketiga-tiga pemboleh ubah bersandar merentasi pemboleh ubah bebas adalah homogen dalam sampel kajian.

Jadual 7: Ujian Levene berdasarkan jantina

\begin{tabular}{lcccc}
\hline $\begin{array}{l}\text { Pemboleh Ubah } \\
\text { Bersandar }\end{array}$ & Nilai F & dK1 & dK2 & $\begin{array}{c}\text { Tahap } \\
\text { Signifikan } \\
\text { (p) }\end{array}$ \\
\hline Global & 2.203 & 4 & 25 & .098 \\
Penyelesaian & 1.669 & 4 & 25 & .189 \\
Masalah & 1.187 & 4 & 25 & .341 \\
Sokongan & & & & \\
\hline
\end{tabular}

Kemudian ujian Levene dilaksanakan untuk melihat kesamaan varian bagi pemboleh ubah bersandar merentasi kategori pemboleh ubah bebas yang dikaji. Dapatan ujian Levene seperti jadual 7 menunjukkan bahawa varian dan kovarian bagi semua pemboleh ubah adalah sama. Nilai yang diperoleh pada pemboleh ubah bersandar iaitu strategi membaca global daripada analisis ujian Levene yang dijalankan adalah tidak signifikan $[\mathrm{F}(4,25)=2.203, \mathrm{p}=.098(\mathrm{p}>0.05)]$. Manakala nilai yang tidak signifikan ditunjukkan melalui ujian Levene pada pemboleh ubah bersandar strategi membaca penyelesaian masalah $[\mathrm{F}(4,25)=1.669, \mathrm{p}=.189(\mathrm{p}>0.05)]$. Pemboleh ubah bersandar strategi membaca sokongan juga menunjukkan nilai tidak signifikan $[\mathrm{F}(4,25)=1.187, \mathrm{p}=.341 \quad(\mathrm{p}>0.05)]$. Hal ini menunjukkan tidak terdapat perbezaan varian pada ketiga-tiga pemboleh ubah tersebut.

Jadual 8: Analisis MANOVA

\begin{tabular}{|c|c|c|c|c|c|c|c|}
\hline Kesan & & $\mathbf{N}$ & $\begin{array}{c}\text { Nilai } \\
\text { Pillai } \\
\text { Trac } \\
\text { e }\end{array}$ & $\begin{array}{c}\text { Nilai } \\
\text { F }\end{array}$ & $\begin{array}{c}\text { dK } \\
\text { antara } \\
\text { kumpula } \\
\text { n }\end{array}$ & $\begin{array}{c}\text { dK dalam } \\
\text { kumpula } \\
n\end{array}$ & $\begin{array}{c}\text { Tahap } \\
\text { Signifika } \\
\text { n } \\
\text { (p) }\end{array}$ \\
\hline $\begin{array}{l}\text { Pencapaia } \\
\text { n Bahasa } \\
\text { Arab }\end{array}$ & $\begin{array}{l}\text { A } \\
\text { A- } \\
\text { B+ } \\
\text { B } \\
\text { B- }\end{array}$ & $\begin{array}{l}4 \\
18 \\
5 \\
1 \\
2 \\
\end{array}$ & .285 & .655 & 12.000 & 75.000 & .788 \\
\hline
\end{tabular}

Jadual 8 menunjukkan analisis MANOVA yang dilaksanakan untuk menentukan perbezaan strategi metakognitif membaca teks berdasarkan pencapaian pelajar. Dapatan ujian MANOVA jelas menunjukkan bahawa tidak terdapat perbezaan antara pencapaian pelajar dalam penggunaan strategi metakognitif membaca teks (strategi global, strategi penyelesaian masalah, strategi sokongan). Hal ini ditunjukkan oleh nilai Pillai's Trace $=.285, \mathrm{~F}=.655$ dan $\mathrm{p}=.788<0.05$. Oleh itu, hipotesis nul yang 
menyatakan tidak terdapat perbezaan skor min strategi metakognitif membaca teks mengikut pencapaian pelajar gagal untuk ditolak dan menunjukkan bahawa kesemua pelajar tidak mengira tahap pencapaian dalam bahasa Arab menggunakan strategi metakognitif membaca teks ketika mempelajari bahasa Arab.

\section{Hubungan Strategi Metakognitif Membaca Teks dengan Jantina}

Adakah terdapat hubungan strategi metakognitif membaca teks (strategi membaca global, strategi membaca penyelesaian masalah dan strategi membaca sokongan) dengan jantina pelajar ketika mempelajari bahasa Arab? Bagi menjawab persoalan kajian tersebut, analisis korelasi spearman dilaksanakan untuk mengenal pasti hubungan antara strategi metakognitif membaca teks dengan jantina dalam mempelajari bahasa Arab. Keputusan analisis korelasi Spearman's Rho adalah seperti yang ditunjukkan dalam jadual 9.

Jadual 9: Analisis Korelasi Spearman's Rho hubungan antara strategi metakognitif membaca teks dengan jantina dalam mempelajari bahasa Arab

\begin{tabular}{lcccc}
$\begin{array}{l}\text { Strategi } \\
\begin{array}{l}\text { Metakognitif } \\
\text { Membaca Teks }\end{array}\end{array}$ & $\mathbf{N}$ & $\mathbf{R}$ & $\begin{array}{c}\text { Jantina } \\
\text { Sig. } \\
(\mathbf{p})\end{array}$ & $\begin{array}{c}\text { Interpretasi } \\
\text { Kekuatan } \\
\text { Hubungan }\end{array}$ \\
\hline $\begin{array}{l}\text { Global } \\
\begin{array}{l}\text { Penyelesaian } \\
\text { Masalah }\end{array}\end{array}$ & 30 & .196 & .298 & Lemah \\
$\begin{array}{l}\text { Sokongan } \\
\text { Keseluruhan }\end{array}$ & 30 & .183 & .332 & Lemah \\
\hline
\end{tabular}

Berdasarkan analisis korelasi Spearman's Rho yang ditunjukkan dalam jadual 9, secara keseluruhan didapati bahawa tidak terdapat hubungan yang signifikan antara strategi metakognitif membaca teks dengan jantina ketika mempelajari bahasa Arab $[\mathrm{r}=.063$ dan sig $=.742(\mathrm{p}>0.05)]$. Selain itu, hasil analisis mendapati kekuatan hubungan adalah lemah meskipun keputusan menunjukkan bahawa hubungan tersebut adalah tidak signifikan.

Dapatan juga menunjukkan nilai pekali korelasi bagi aspek strategi membaca global adalah $[\mathrm{r} .196=$ dan sig $=.298(\mathrm{p}>0.05)$ ] dan nilai korelasi yang terhasil menunjukkan hubungan yang disamping nilai kebarangkalian juga didapati lebih besar dari aras keertian. Oleh itu, dapatan menunjukkan tidak terdapat hubungan yang signifikan antara strategi membaca global dengan jantina.

Bagi aspek strategi membaca penyelesaian masalah, dapatan menunjukkan nilai pekali korelasi dan nilai kebarangkalian adalah $[\mathrm{r}=.183$ dan sig $=.332(\mathrm{p}>0.05)]$. Nilai pekali korelasi yang ditunjukkan adalah lemah dan nilai kebarangkalian pula adalah lebih besar dari aras keertian $p>0.05$. Oleh itu, dapatan menunjukkan tidak terdapat hubungan yang signifikan antara strategi membaca penyelesaian masalah dengan jantina.

Manakala aspek strategi membaca sokongan pula menunjukkan nilai pekali korelasi dan nilai kebarangkalian adalah $[\mathrm{r}=.107 \mathrm{dan} \operatorname{sig}=.574(\mathrm{p}>0.05)]$. Nilai pekali korelasi yang ditunjukkan adalah lemah dan nilai kebarangkalian pula adalah lebih besar dari aras keertian $\mathrm{p}>0.05$. Oleh demikian, dapatan menunjukkan tidak terdapat hubungan yang signifikan antara strategi membaca sokongan dengan jantina.

\section{Hubungan Strategi Metakognitif Membaca Teks dengan Pencapaian Pelajar}

Adakah terdapat hubungan strategi metakognitif membaca teks (strategi membaca global, strategi membaca penyelesaian masalah dan strategi membaca sokongan) mengikut pencapaian pelajar ketika mempelajari bahasa Arab? Bagi menjawab persoalan kajian tersebut, analisis korelasi Spearman's Rho dilaksanakan untuk mengenal pasti hubungan antara strategi metakognitif membaca teks dengan 
pencapaian pelajar ketika mempelajari bahasa Arab. Keputusan analisis korelasi Spearman's Rho adalah seperti yang ditunjukkan dalam jadual 10.

Jadual 10: Analisis Korelasi Spearman's Rho hubungan antara strategi metakognitif membaca teks dengan pencapaian pelajar dalam mempelajari bahasa Arab.

\begin{tabular}{lcccc}
\hline $\begin{array}{l}\text { Strategi } \\
\begin{array}{l}\text { Metakognitif } \\
\text { Membaca Teks }\end{array}\end{array}$ & $\mathbf{N}$ & $\begin{array}{l}\text { Pencapaian Pelajar } \\
\text { R }\end{array}$ & $\begin{array}{c}\text { Sig. } \\
(\mathbf{p})\end{array}$ & $\begin{array}{c}\text { Interpretasi } \\
\text { Kekuatan } \\
\text { Hubungan }\end{array}$ \\
\hline $\begin{array}{l}\text { Global } \\
\begin{array}{l}\text { Penyelesaian } \\
\text { Masalah }\end{array}\end{array}$ Sokongan $_{\text {Keseluruhan }}^{30}$ & -.102 & .592 & $\begin{array}{c}\text { Lemah } \\
\text { Lemah }\end{array}$ \\
\hline
\end{tabular}

Secara keseluruhan, jadual 10 menunjukkan tidak terdapat hubungan yang signifikan antara strategi metakognitif membaca teks dengan pencapaian pelajar dalam mempelajari bahasa Arab $[\mathrm{r}=-.026$ dan sig=.890 (p>0.05)]. Walaupun kekuatan hubungan adalah lemah, namun begitu, analisis ujian mendapati bahawa hubungan tersebut adalah tidak signifikan. Oleh itu, hasil ujian tidak dapat membuktikan bahawa sama ada hubungan antara strategi metakognitif membaca teks dengan pencapaian pelajar ketika mempelajari bahasa Arab adalah positif atau negatif.

Secara terperinci, bagi aspek strategi membaca global, dapatan menunjukkan nilai pekali korelasi dan nilai kebarangkalian adalah $[\mathrm{r}-.102=$ dan sig $=.592 \quad(\mathrm{p}>0.05)]$. Nilai korelasi yang didapati adalah lemah dan nilai kebarangkalian juga didapati lebih besar dari aras keertian $\mathrm{p}>0.05$. Oleh itu, dapatan menunjukkan tidak terdapat hubungan yang signifikan antara strategi membaca global dengan pencapaian pelajar.

Dapatan juga menunjukkan nilai pekali korelasi dan nilai kebarangkalian bagi aspek strategi membaca penyelesaian masalah adalah $[\mathrm{r}=-.149$ dan sig=.431 ( $\mathrm{p}>0.05)]$. Nilai korelasi yang terhasil adalah lemah dan nilai kebarangkalian juga didapati lebih besar dari aras keertian $p>0.05$. Justeru, dapatan menunjukkan tidak terdapat hubungan yang signifikan antara strategi membaca penyelesaian masalah dengan pencapaian pelajar.

Seterusnya, dapatan bagi aspek strategi membaca sokongan menunjukkan bahawa nilai pekali korelasi dan nilai kebarangkalian adalah $[\mathrm{r}=.005$ dan sig $=.980(\mathrm{p}>0.05)]$. Nilai korelasi yang terhasil pula menunjukkan hubungan yang lemah, manakala nilai kebarangkalian didapati lebih besar dari aras keertian $p>0.05$. Sehubungan itu, dapatan menunjukkan tidak terdapat hubungan yang signifikan antara strategi membaca sokongan dengan pencapaian pelajar.

\section{Perbincangan Kajian}

Secara keseluruhan, hasil kajian menunjukkan bahawa kesemua responden menggunakan strategi metakognitif membaca teks ketika mempelajari bahasa Arab walaupun penggunaan strategi tersebut berada pada tahap rendah. Namun begitu, ketiga-tiga strategi metakognitif membaca teks iaitu strategi global, strategi penyelesaian masalah dan strategi sokongan didapati berada pada tahap sederhana. Strategi global memperoleh min 2.43, strategi membaca penyelesaian masalah memperoleh min 2.50 dan strategi sokongan memperoleh min 2.40. Hal ini bermakna responden menyedari bahawa penting bagi mereka menggunakan strategi metakognitif membaca teks dalam pembelajaran mereka. Menurut Alhaqbani \& Riazi (2012), penggunaan strategi membaca dalam pembelajaran kemungkinan disebabkan membaca bagi tujuan akademik menggalakkan pembaca menggunakan lebih banyak strategi kerana membaca bagi tujuan akademik mempunyai permintaan kogntitif yang tinggi. Dapatan ini ada hubungan dengan pencapaian bahasa Arab responden yang mana 18 orang memperoleh gred A. Dapatan ini selari dengan dapatan Farah Aida \& Che Nidzam (2014) dan Mazli Sham \& Saemah 
(2014) yang menyatakan bahawa kesedaran metakognitif dalam pembelajaran merupakan faktor penting kerana jika kesedaran metakognitif pelajar meningkat, pencapaian akademik juga akan meningkat.

Dapatan kajian ini juga menyamai beberapa kajian terdahulu seperti kajian Al-Dawaideh (2013), Shikano (2013), Keshavarz \& Ghamoushi (2014) dan Fitrisia et.al (2015) dalam kesedaran metakognitif terhadap strategi membaca. Kesemua kajian ini mendapati pelajar menggunakan strategi metakognitif membaca teks dalam meningkatkan kefahaman dalam bacaan ketika proses pembelajaran. Hasil kajian juga mendapati strategi penyelesaian masalah merupakan strategi yang tertinggi dalam strategi metakognitif membaca teks.

Dapatan kajian juga menunjukkan strategi metakognitif membaca teks yang digunakan oleh pelajar tidak mempunyai perbezaan yang signifikan antara jantina dan pencapaian pelajar. Kedua-dua faktor berikut menunjukkan nilai min strategi metakognitif membaca teks yang rendah. Maka dapat dirumuskan bahawa, kesemua pelajar bahasa Arab walaupun tahap penggunaan strategi metakognitif berada pada tahap rendah, mereka mempunyai kesedaran dalam menggunakan strategi metakognitif membaca teks dalam proses pembelajaran mereka.

Hasil penelitian analisis MANOVA telah menunjukkan tahap strategi metakognitif membaca teks tidak mempunyai perbezaan yang signifikan anara jantina. Hasil analisis telah menunjukkan bahawa strategi global, strategi penyelesaian masalah dan strategi sokongan oleh pelajar lelaki dan perempuan adalah sama. Dapatan ini bertentangan dengan dapatan Al-Dawaideh (2013) menunjukkan pelajar perempuan mempunyai strategi metakognitif lebih tinggi. Selain itu, dapatan kajian juga menunjukkan tidak terdapat perbezaan yang signifikan tahap strategi metakognitif membaca teks terhadap pencapaian pelajar. Hal ini menunjukkan pelajar yang mempunyai pencapaian lebih baik dari pelajar lain mempunyai tahap penggunaan strategi metakognitif membaca teks yang hampir sama dalam proses pembelajaran mereka. Dapatan analisis korelasi Spearman-Rho pula menunjukkan tidak terdapat hubungan yang signifikan dan dapatan menunjukkan hubungan yang lemah antara strategi metakognitif membaca teks dengan jantina dan pencapaian pelajar.

Hasil perbincangan mendapati terdapat implikasi terhadap pengajaran dan pembelajaran iaitu para guru dapat menerapkan dan memupuk kesedaran strategi metakognitif dalam aktiviti pengajaran dan pembelajaran bahasa Arab. Tenaga pendidik bahasa Arab dapat memanfaatkan hasil kajian untuk merancang pengajaran dan pembelajaran dengan memupuk kesedaran strategi metakognitif dalam proses pembelajaran teks Arab. Hal ini telah dilakukan dalam kajian Albazi dan Shukri (2016) yang meneliti bagaimana latihan strategi metakognitif boleh membantu meningkatkan kesedaran strategi metakognitif dan pemahaman dalam pembacaan.

Dapatan kajian ini menunjukkan terdapat dua limitasi yang telah dikenalpasti sepanjang kajian. Pertama, kajian ini meninjau hubungan strategi metakognitif membaca teks dengan jantina dan pencapaian pelajar dan berkemungkinan masih terdapat pembolehubah lain yang boleh dikaji untuk mendapatkan data yang lebih mendalam bagi kajian. Kedua, data ini hanya mewakili persepsi pelajar sahaja dan tidak mewakili pandangan tenaga pengajara terhadap penggunaan strategi metakognitif membaca teks.

Kajian ini merupakan kajian tinjauan dan data dikumpulkan melalui instrumen soal selidik. Kajian lanjutan disarankan menggunakan reka bentuk kajian kualitatif melalui temu bual pelajar dan guru bahasa Arab di institut pengajian tinggi yang lain bagi menyokong dapatan kajian kuantitatif dan mendapatkan dapatan kajian yang lebih dalam untuk menyokong dapatan kajian. Selain itu, kajian ini meneliti strategi metakognitif dalam kalangan pelajar bahasa Arab di UKM. Kajian lanjutan disarankan agar meninjau kesedaran strategi metakognitif di institusi pengajian lain agar dapatan kajian dapat diperluaskan sekaligus dapat digeneralisasikan kepada semua pelajar bahasa Arab di institusi pengajian tinggi yang lain. Seterusnya, kajian ini hanya memfokuskan strategi membaca dan kajian lanjutan boleh diperluaskan pada strategi menulis, mendengar dan bertutur dalam bahasa Arab. 


\section{Kesimpulan}

Keputusan hasil kajian ini menunjukkan responden mempunyai tahap strategi metakognitif membaca teks yang rendah. Hasil kajian menunjukkan tidak terdapat perbezaan yang signifikan dalam strategi metakognitif membaca teks berdasarkan jantina dan pencapaian pelajar ketika mempelajari bahasa Arab. Dapatan kajian jelas mendapati penggunaan strategi metakognitif membaca teks antara lelaki dan perempuan serta pencapaian pelajar adalah sama. Selain itu, hasil kajian menunjukkan tidak terdapat hubungan antara strategi metakognitif dengan jantina dan pencapaian pelajar ketika mempelajari bahasa Arab. Namun begitu, hasil kajian menyumbang kepada dapatan bahawa pelajar sememangnya menggunakan strategi metakognitif membaca teks dalam pembelajaran bahasa Arab. Keupayaan pelajar dalam penggunaan strategi metakognitif menunjukkan mereka mempunyai kemampuan metakognitif yang tinggi dan perlu digilap dari awal proses pembelajaran. Hal ini kerana, menurut Paris dan Winograd (1990) (dalam Mokhtari \& Reichard 2002) kemampuan metakognitif dapat meningkatkan pembelajaran secara akademik dan daya motivasi.

\section{Rujukan}

Al-Dawaideh, A.M. (2013). Assessing metacognitive awareness of reading strategy use forstudents from the faculty of education at the university of king abdulaziz. MevlanaInternational Journal of Education (MIJE), 3(4), 223-235.

Albazi, S. Shukri, N. (2016). Evaluating the effect of metacognitive strategy training on reading comprehension of female students at KAU. International Journal of Applied Linguistics \& English Literature, 5(3), 172-183.

Alhaqbani, A. Riazi, M. (2012). Metacognitive awareness of reading strategy use in Arabic as a second language. Reading in a Foreign Language, 24(2), 231-255.

Alsheikh, N.O. Mokhtari, K. (2011). An Examination of the metacognitive reading strategiesused by native speakers of Arabic when reading in English and Arabic. English Language Teaching, 4(2), 151-160.

Azman Goh \& Goh, Y. S. (2010). Situasi pembelajaran bahasa asing di institusi pengajian tinggi: perbandingan antara bahasa Arab, bahasa Mandarin dan bahasa Perancis. AJTLHE, 2, 9-20.

Chamot, A. L. (2001). The role of learning strategies in second language acquisition. (pnyt.). Breen, M. P. (dlm). Learner Contributions to Language Learning. England Pearson Education Limited.

Chua, Y. P. (2011). Kaedah Penyelidikan. Kuala Lumpur: McGraw-Hill Malaysia Sdn. Bhd.

Farah Aida \& Che Nidzam. (2014). Kesedaran strategi metakognitif dan kemahiran berfikir aras tinggi dalam kalangan pelajar Biologi. Jurnal Penyelidikan Pendidikan (KPM), 15.

Fitrisia, D. Tan \& K. E. Yusuf, Y.Q. (2015). Investigating metacognitive awareness of reading strategies to strengthens students' performance in reading comprehension. Asia Pacific Journal of Educators and Education, 30, 15-30.

Goh, C. (2010). Listening as a Process: Learning Activities for Self-Appraisal and Self-Regulation. (dlm). English Language Materials. Klett Ernst/ Schulbuch (https://www.academia.edu/953247/8_Listening_as_process_Learning).[25 DECEMBER 2015].

Keshavars, M. H. \& Ghamoushi, M. (2014). A comparative study of metacognitive awareness of reading strategies among monolingual and bilingual Iranian EFL learners.

Khonamri, F., \& Kojidi, M. E. (2011). Metacognitive awareness and comprehension and monitoring in reading ability of Iranian EFL learners. PUBLIC, 13(2), 99-111.

Mazli Sham Abdullah \& Saemah Rahman. 2014. Gaya pembelajaran dan kesedaran metakognitif dalam kalangan pelajar aliran sains. Proceeding of the Social Sciences Research ISSR 2014.

Mokhtari, K., \& Reichard, C. A. (2002). Assesing students's metacognitive awareness of reading strategies. Journal of Educational Psychology, 94(2), 249-259.

Noraini Idris. 2010. Penyelidikan dalam Pendidikan. Kuala Lumpur: McGraw-Hill Malaysia Sdn. Bhd.

Nik Nur Fadhillah Abdul Razak. (2015). Kesedaran Metakognitif dan Pemupukan Perkembangan Metakognitif Guru Matematik Sekolah Menengah. Tesis Sarjana. Fakulti Pendidikan, UKM. 
DOI: https://doi.org/10.47405/mjssh.v6i4.762

Shikano, M. (2013). A Quantitative survey on metacognitive awareness of reading strategy use in English by Japanese university students. International Education Centre Journal, 14, 11-24.

Tavakoli, H. (2014). The effectiveness of metacognitive strategy awareness in reading comprehension: the case of Iranian university EFL learners. The Reading Matrix, 14(2), 314-336. 